\title{
NATURE AND ASSESSMENT OF LOSSES CAUSED BY SUGARCANE BORERS (*)
}

\author{
by \\ J. Ruinard \\ Contre Por Agricultural Research in Surinam, Paramaribo, Suritam.
}

\begin{abstract}
Uf the two main types of sugareane borets, viy. lop and stalk borers, the hatter are generally more harmful than the former. In the goung erop statk horers eause dead herats, but at later sotges their attack is normally restrieterl to tho: joints, exeept in \{athosl\} mature wate when agitin milly tups may be: destoroyed. In this paper emphasis is on assessing tho extent of infestation and the melationslip between stalk borel injury and loss of sugar. Various criteriatand methods

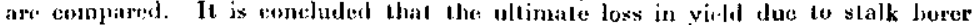
inlestation may be as latre as $1 \%$ for each $1 \%$ joints hired, all forms of injury includeil.
\end{abstract}

Borers feeding on sugarcane are diverse, numerous and usually of limited geographical distribution. However, they all inflict heavy damage upon the crop, thus causing borers to rank among the most dreaded pests in nearly all areas where sugarcane is grown.

Many workers have published data on losses caused by borers, but unfortunately there are large personal and regional differences in the methods of assessment. In this paper an attempt is made to summarize part of the work that has been done so far, thereby paying special attention to the methodology. To facilitate this, the borers are classified into two main types, viz. top borers and stalk borers (also named internode or stem borers, and including shoot borers). Rootstock borers are ignored because they are of minor importance.

\section{Top borers}

Top borcrs enter the stalk through the leaf spindle and on their way downward usually destroy the growing point. In tropical areas infestation of young sugarcane stands is generally considered harmless provided the attack is random, because normally all shoots destroyed

(*) Presented at the symposium (OIt.B on borers of graminaceous plants. Paris, 2'th sept. 1970. 
are replaced by younger tillers. But since this process involves a relative rejuvenation of the crop, in regions with a limited growing period, the net result may be a reduction in weight and sugar content of the cane at the time of harvest.

Data to this effect have been published by Sidiqui (1964). By weekly observations of several cane fields in India, he traced the development of all mother shoots and tillers from planting to harvest. He found that in older fields top borer infestation reduces the number of millable stalks and lowers the weight and sucrose per cent juice (and presumably the juice per cent cane) of the attacked but still millable stemis. Kalka \& Chaldiaky (1964) proved these losses to be greater with a longer period between death of the growing point and harvest. It is still uncertain whether the surviving stalks provide compensation for these losses, and, if so, to what extent.

\section{Stalk borers}

Nature of injury. Sugarcane at any stage of growth is liable to attack by stalk borers. Larvae present in the seed cane may destroy buds before they have germinated and shoots before they have emerged. In the young crop infestation by stalk borers results in the characteristic dead hearts, a phenomenon also encountered often in maturing fields. During the period of rapid stem elongation, however, the attack is normally restricted to the (often still young) joints. It is not unlikely that the cane's growth pattern is primarily responsible for this typical form of injury.

In its effect upon yield, borer attack resulting in destruction of the growing point, i. e. in the death of entire shoots or stalks, obviously differs greatly from infestation restricted to the nodes and internodes. Thus also, from an economic point of view, it is an important question why dead tops occur particularly in the beginning and at the end of the growing period. The answer may be in the biology of the borers. In Java, the majority of larvae feed preferably in nearly full grown but still weak rinded joints which are closely surrounded by green leaf sheaths (RUINARD, 1958). There are indications in the literature that the same applies to some of the predominant species elsewhere. Only in young and old canes, forming short joints, is the growing point very near to the favourite joints. Consequently, it is standing a greater chance of being destroyed by the tunneling borers.

Mortality before emergence. The extent of mortality before emergence can easily be found by counting the primary shoots present on completion of emergence in representative parts of the field and deducting this figure from the potential number of primary shoots. Normally, good seed cane planted in the right way produces several times more primaries than are needed for the development of a full 
stand of cane. Consequently, only a very high mortality will result in permanently reduced stands having a lower yield potential. In areas with a limited length of time between planting and harvest, the relative rejuvenation of the crop resulting from the replacement of primaries by tillers may lead to reduced yields. A loss in yield is also inevitable where this type of injury causes long gaps in the rows and where rots become established in the borer tunnels.

Shoot and stalk mortality. It is still a matter of speculation whether a measurable relationship exists between shoot mortality in young cane (dead hearts) and yield. However, it is generally felt that a vigorous crop can stand a rather heavy infestation without harm, due to its ability to replace the lost shoots by younger tillers. An exception to that rule is again found in regions characterized by a limited growing period. It also stands to reason that dead hearts are more likely to effect a loss in yield as they occur at a later stage. Counts of dead hearts in representative parts of a field should therefore be repeated rather frequently. Special attention must be given to the occurrence of gaps in the rows.

During its elongation period sugarcane may also lose stalks by borer attack. Sometimes the growing point is destroyed; in other cases stalks break on heavily bored joints. This loss tends to be of little importance, because normally only few (and then mainly suppressed and weak) stems fall a victim to these forms of injury. Moreover, in a healthy stand of cane that is still growing vigorously, the loss of a limited number of stalks, provided they are randonily distributed, is to a large extent compensated by a better development of neighbouring stems. Again by means of frequent surveys in representative parts of a field, reliable data on the loss of stalks at the different stages of growtl can be obtained.

In contrast to dead hearts in younir cane, the presence of dead tops in maturing cane cannot be taken lightly. A study was done in Java (Rinarin, 1958), checking a total of 10,000 randomly distributed stalks in representative parts of several fields fortnightly during the final four months before harvest. It was found that a stalk may lose $1 / 4 \%$ of its weight and the juice $1 / 3 \%$ of its available sucrose per cent juice for each day between the dates of death and harvest. The combined effect is a $1 / 2 \%$ reduction per day in sugar yicld. The actual field loss is even higher than could be demonstrated, because neither the reduction in juice per cent cane was taken into account, nor the fact that normally a large proportion of stems thus killed disappear before harvest or become non-millable. Besides, any compensation at that stage of growth seems out of the question.

Infestation of joints. The extent of infestation of the joints may be expressed in different ways. The generally used criterion is the per cent joints bored as assessed by external examination of the stems. 
The number of stalks needed for a reliable estimation of this percentage in a mature field is rather small provided they are taken at random. Investigations in Java (RUINARD, 1958) have shown that in mature fields ranging from 0.025 to 3.2 ha, samples of 20 stalks provide a close estimation of the true per cent joints bored. As the loss in yield of an infested stalk proved not only to depend on the number of joints bored but also on their position on the stalk, it is necessary to make separate assessments of the per cent joints bored in various parts of the stems, e.g. the bottom and top halves.

Other criteria have been proposed but are less exact or more cumbersome. 'The per cent joints bored determined by internal examination of the stalks, for instance, cannot easily be assessed. The per cent stalks bored, another well known criterion, is not sufficiently accurate, even when applied to very large numbers of stems (fig. 1). It is true that various authors (Banciniwal.a \& Martorei,, , 1954; Bax(i)IWAIA it al., 1967) observed - in contrast to the curvilinear relationship shown in fig.. 1 - a significant linear regression of per cent joints bored on per cent stalks bored, but unfortunately they had only a narrow scope of percentages stalks bored at their disposal.

Borer injury in a joint not only adversely affects that joint by reducing its weight, juice content and available sucrose per cent juice (table 1), but it also has a marked influence upon the other joints of the same stalk (table 2). It lowers the quality of the juice in the older joints and interferes with the development of the younger part of the stem by reducing its number of joints and their average weight. This is so whether these older and younger joints themselves are infested or not. As a result, any assessment of yield loss in infested stems by counting and comparing the bored and unbored joints is bound to produce unrealistical figures. To a certain extent the same applies for comparison of whole stalks with different infestation percentages taken from the same homogeneous stand, because the total loss also depends on the position of injury. Loss assessments should therefore be based on comparison of parts of stalks, e.g. the lower and upper halves, and be designed in such a way that the mutual influence of these parts is brought to light.

The outcome of the various experiments described in the literature and conducted in different parts of the world shows a considerable variation. Generally speaking and ignoring the position of injury, it seems justified to estimate the loss in available sucrose per infested stalk at almost $1 / 2 \%$ for each $1 \%$ joints bored. Whether sugarcane can partly or fully compensate losses due to infestation of joints has not been investigated. There is, however, every reason to assume that it is not able to do so.

A comparison of single joints, stalks or parts of stalks, is necessarily limited to samples. Although this indirect procedure is correct, 


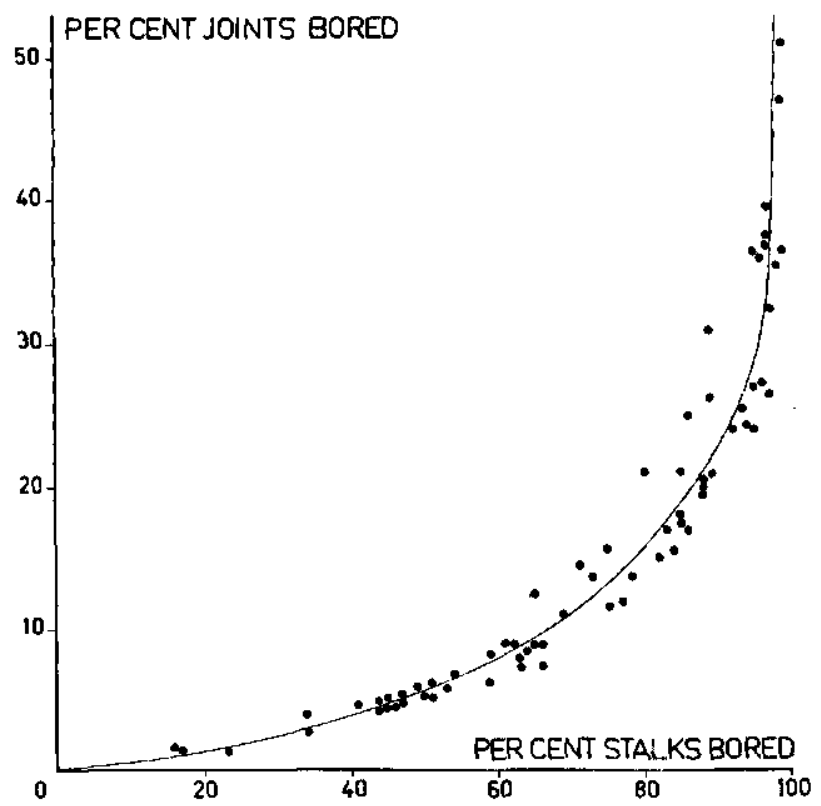

Fig. 1. Relationship between per cent stalks bored and per cent joints bored in samples containing 500-1200 full grown cane stems (region : Java; varieties : POJ 2878 and POJ 3016; RuINiRD, 1958).

\section{TABLE 1}

Average loss in yield of bored joints as a percentage of the yield of unbored joints belonging to the same stem parts

(Java, 9 samples of 300 and 10 samples of 50 stalks respectively).

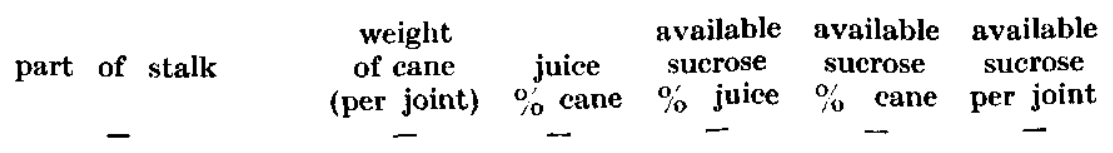

\section{HAZELhofk (1928) :}

$\begin{array}{llllll}\text { lower part } \ldots \ldots \ldots \ldots & \mathbf{0 . 3} & 21.7 & \mathbf{7 . 0} & \mathbf{2 7 . 2} & \mathbf{3 2 . 9} \\ \text { central part } \ldots \ldots \ldots \ldots & \mathbf{7 . 8} & \mathbf{1 0 . 4} & \mathbf{6 . 9} & \mathbf{1 6 . 6} & \mathbf{2 3 . 4} \\ \text { top part } \ldots \ldots \ldots \ldots \ldots & \mathbf{0 . 4} & 12.8 & \mathbf{9 . 4} & \mathbf{2 1 . 0} & \mathbf{2 1 . 0} \\ \text { average } \ldots \ldots \ldots \ldots \ldots & \mathbf{5 . 8} & 15.0 & \mathbf{7 . 8} & \mathbf{2 1 . 6} & \mathbf{2 6 . 0}\end{array}$

Ruinard (1958) :

$\begin{array}{lrrrrr}\text { lower part } \ldots \ldots \ldots \ldots & \mathbf{3 . 4} & 2.8 & 14.6 & 17.0 & 19.4 \\ \text { central part } \ldots \ldots \ldots \ldots & \mathbf{7 . 5} & 4.7 & 10.8 & 15.0 & 21.4 \\ \text { top part } \ldots \ldots \ldots \ldots \ldots & 7.9 & 14.2 & 12.1 & 24.6 & 30.7 \\ \text { average } \ldots \ldots \ldots \ldots \ldots & 6.2 & 7.3 & 12.5 & 18.9 & 23.8\end{array}$




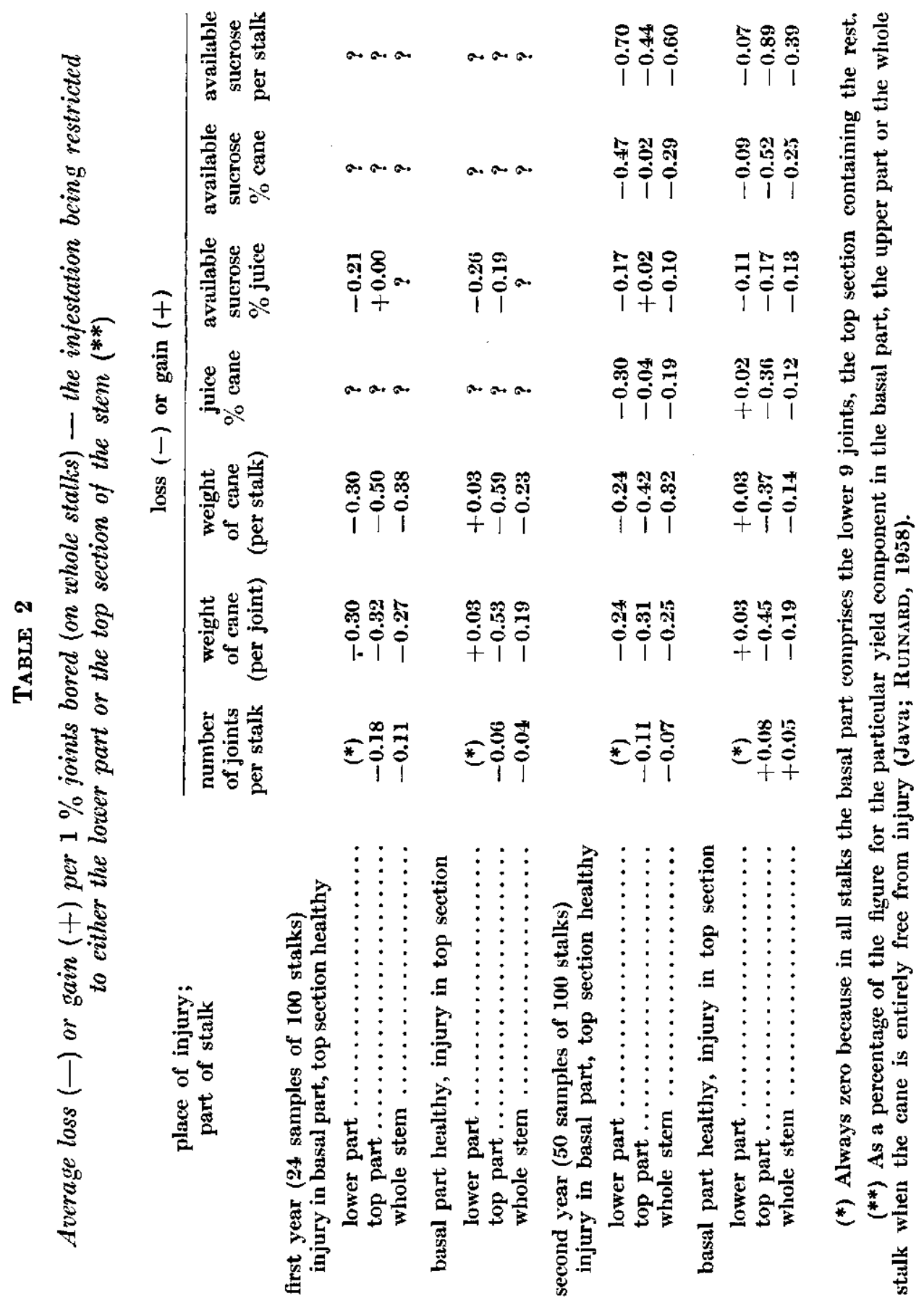


provided the samples are representative and not too small, a direct estimation of the various forms of loss would be more satisfactory. This direct approach has been shown to be possible in field trials by comparing identical stands of cane which only differ in degree of infestation. Mathes, Baum \& Charpentier (1957) referred to such an experiment in Louisiana in which three levels of borer infestation were employed by dusting the cane with sulphur to increase the infestation and with cryolite to decrease it. The relationship between sugar yield and per cent joints bored was found to be linear. The loss in yield of sugar per stalk for each $1 \%$ joints bored amounted to $0.5 \%$ of the yield of unbored canes. McQuire, Matues \& Charpentier (1967) went even further in producing different levels of infestation at different locations on the stalks by applying various insecticides during several periods of growth.

Additional losses. The wounds in the stalk caused by borers provide an entrance to rot organisms, such as fungi and bacteria. These are capable of inverting sucrose and in this way lower the sugar yield of the crop. They may also adversely affect the weight of the cane and its juice content. As some of these organisms are very common, it is obvious that in normal field work their part in the losses cannot be separated from that due to the borers themselves.

There is also greater difficulty in milling borer-infested canes because they contain less juice. Since the purity of the juice is lower, the clarification takes more time. For the samc reason the syrup are thicker, thus retarding the crystallization of the sugar. Heavily infested cane generally produces a very fine bagasse of low fuel value, so that a factory grinding such a crop may be confronted with a shortage of fuel.

Where the young tops of millable stalks are being used as seed cane, a high per cent joints bored in these tops may render them worthless as planting material.

Ultimate loss in yield. The ultimate loss in yield which stalk borers inflict upon a field of sugarcane may be calculated by adding up all partial losses mentioned above. It goes without saying that this can be realized in small stands of cane, such as field experiments, but that it would be impracticable to apply this procedure in largescale work.

Some major borer species prefer young joints. It is likely, therefore, that a definite correlation exists between the per cent joints bored and the distribution of these joints on the stems on the one side, and quantitative figures of shoot and stalk mortality throughout the lifetime of the crop on the other. It seems worthwhile to ascertain in future research whether this assumption is correct. If it is shown to be right, then it must be possible by special experiments to deternine the regression of both percentage joints bored and their average 
position on total loss in yield. Perhaps it would appear necessary to differentiate between regions and varieties, but this would not be detrimental to the method.

Once loss of sugar has been correlated to such a comprehensive index, the actual field loss over wide areas could be determined from these two criteria in rather small, representative samples. Often it would not be necessary to collect special samples for this purpose, because samples taken to ascertain the degree of maturity of the crop - a practice on many plantations all over the world - are also suitable for estimating the extent and position of borer injury in the fields they represent.

Approximate figures derived from experiments on control of borers by insecticides in Java show that the ultimate loss in yield due to stalk borer infestation may be as large as $1 \%$ for each $1 \%$ joints bored (Rusind), 1958), all forms of injury included.

\section{RÉSLMÉ}

Nature et évaluation des pertes clues aux foreurs de la canne à sucre

L'existence d'une relation rationnelle entre la mortalité des tiges des jeunes plantes et la récolte peut être considérée comme spéculative. Dans des champs de canne qui montrent une croissance vigoureuse, ces pertes - pourvu qu'elles soient distribuées "au hasard" - sont largement compensées par un meilleur développement des tiges voisines.

Par contre, la mort des tiges chez des plantes à l'âge de la maturation constitue un dommage plus grave. D'après des recherches faites à Java une tige peut perdre journellement $0,25 \%$ de son poids et $0,33 \%$ de sa quantité de sucrose dans le jus pendant toute la période entre sa mort et la récolte. Cne compensation à ce stade de la croissance ne peut intervenir.

Actuellement le pourcentage d'entre-nouds attaqués, qui est le critère pour estimer la perte, est déterminé par un examen externe des tiges entières. Généralement la diminution du sucrose est estimée à $0,25 \%$ pour chaque pour cent d'entre-nocuds creusés par les chenilles.

Cependant comme la perte ne dépend pas exclusivement du nombre de nœuds percés mais aussi de leur position sur la tige, il convient d'évaluer séparément les pertes dans les parties différentes des tiges, par exemple dans la moitié de la base et la moitié du sommet.

\section{REFERTENGIES}

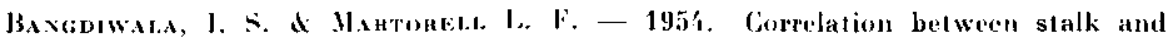
joint infestation by sugarcane moth bores, Diatraen saccharalis fi. - Proc. 8!h congr. int. Soc. Sug. Cane Technol., 593-601.

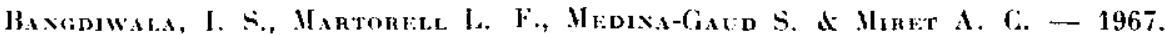
Furlher studies in correlation betwenn stalk and joint infestation by sugarcanr notb-borer, Jiatraen sacharalis (Fabicies) in Puerto Rico. - Proc. 12th Congr. int. Sce. Sug. Cane Trehnol., 1373-1382.

Hazinary, E. J. - 1928. Onderzotingen over den stengelboorder (Diatraea

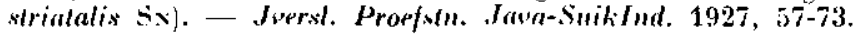




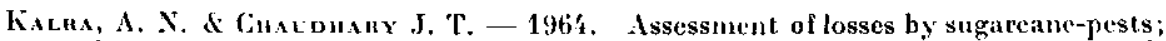
loss caused by top borer of sugareane. - Indian J. Sug. C'ane Res. Des', 8, 261-26't.

Mathes, R., Back, R. J. \& Chanplextur L. J. - 1967. A method of relating yields of sugar and sugareane burer damage. - Pror. 12 th congr. int. Soc. Sug. Cane Technol, 1388-1396.

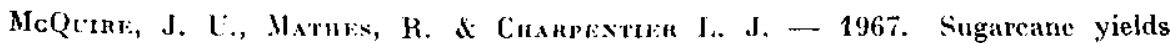
affected by borer infestation and position of injury on stalk. - Proc. 12/h Congr. Jut. Soc. Sing. Cane Technol, 1368-1372.

ReıNaRD, J. - 1958. Investigalions into bionomies, economic importance and possibilities of coutrol of the sugareane stalkboress in Java. - Proetschrifi Lathdboushogesshonl. Wageningen (In dutch, with english summary).

Sinduli, \%. A. -- 196\%. Tillering in sugareane and morlality caused by borers and other factors. - Indian I. Sut. ' 'mue hes. Dev., 8, 265-269. 